\title{
Acción, improvisación y emoción: las bases de la arquitectura ecológica de TYIN Tegnestue
} Action, Improvisation and Emotion: The Foundations of TYIN Tegnestue's Ecological Architecture

\author{
Francisco Javier Maroto Ramos ${ }^{[1]}$, Pedro García Martínez ${ }^{[2]}$ \\ [1] Universidad Politécnica de Madrid, ${ }^{[2]}$ Universidad Politécnica de Cartagena \\ Traducción Translation Traducido por los autores
}

\section{Palabras clave Keywords}

Arquitectura, ecología, TYIN Tegnestue, objeto técnico y social, diseño participativo

Architecture, ecology, TYIN Tegnestue, technical and social object, participatory design

\section{Resumen}

Los cambios globales registrados en el clima urgen a las sociedades actuales a tomar medidas que reduzcan el impacto de las actividades humanas sobre los ecosistemas. La conciencia ecológica ha llegado también al campo de la arquitectura donde se observa que la noción de edificio ecológico es relativa y está estrechamente ligada al contexto y los medios, materiales y humanos. El análisis de la trayectoria de los arquitectos TYIN Tegnestue, desde sus inicios, cuando aún eran estudiantes, hasta su reciente disolución, puede tomarse como un índice crítico para evaluar en qué punto se encuentra la práctica ecológica en la arquitectura. En este texto se estudia su trabajo, con el fin de mostrar los rasgos, las pautas y los valores que lo relacionan con la ecología y el diseño participativo. Son una muestra de la creciente atención que reciben otros arquitectos relacionados con esta forma de entender el proyecto y la obra como vehículos de la cohesión social y la ecología.

\section{Abstract}

Global changes in climate are urging today's societies to reduce the impact of human activities on ecosystems. Ecological awareness has also reached architecture, where the notion of an ecological building is relative and intricately linked to the context and the means, both material and human. The analysis of the trajectory of the architects TYIN Tegnestue, from their beginnings when they were still students until their recent dissolution, can be taken as a critical index to evaluate where ecological practice in architecture stands. This text studies their work to show the features, patterns, and values related to ecology and participatory design. It shows the growing attention that other architects receive about understanding the project and the construction as vehicles of social cohesion and ecology. 
Introducción. Desde la Revolución Industrial, el impacto de las actividades humanas sobre los ecosistemas se ha incrementado progresivamente. Algunos científicos afirman que nos encontramos en una nueva era geológica denominada Antropoceno (1) Aunque la comunidad científica no ha aceptado el término de forma unánime, esta idea revela la influencia que ha adquirido la conciencia medioambiental.

En el ámbito social, las circunstancias geopolíticas y económicas experimentadas a nivel global tras la Segunda Guerra Mundial favorecieron la aparición de movimientos contraculturales, especialmente activos en esta conciencia como reacción al statu quo anterior. En el campo de la arquitectura este desplazamiento contribuyó a la disolución del CIAM y la emergencia de voces disidentes como las de Van Eyck, Alexander, Van Lengen, Turner, Habraken o Rudofsky, que defendían una arquitectura menos dogmática y más comprometida con la comunidad social y el medio.

Las sucesivas crisis socio-económicas experimentadas a comienzos del siglo XXI, han revigorizado esta conciencia, (2) generando un panorama fragmentado, en el que se contraponen diversas corrientes, que difieren tanto en el marco teórico empleado para analizar los problemas medioambientales como en las acciones que se proyectan para afrontarlos. El conjunto de iniciativas ha evolucionado desde una realidad genérica y antropocéntrica hasta una concepción más concreta, 'sociotécnica', (3) en la que se ponderan la tecnología y su impacto en la sociedad. En este escenario, el diseño sostenible se mide por los índices de lo que promueve y significa para la sociedad -entendiéndose que esta ha adquirido ya una conciencia medioambiental-. La concepción ecológica de la arquitectura está condicionada por dos factores, que son la consecuencia del equilibrio entre el desarrollo técnico y la conciencia social: la 'imaginación pragmática' (4) que articula el proyecto, la obra, los medios disponibles y la capacidad de la comunidad para implicarse, desde la responsabilidad y la participación, condicionando el diseño con

Introduction. Since the Industrial Revolution, the impact of human activities on ecosystems has progressively increased. Some scientists claim that we are in a new geological era called Anthropocene. (1) Although the scientific community has not unanimously accepted the term, the concept itself reveals environmental awareness in society.

In the social field, the geopolitical and economic circumstances experienced at a global level after the Second World War favoured the emergence of counter-cultural movements, which were particularly active in this consciousness as a reaction to the previous status quo. In the field of architecture, this displacement contributed to the dissolution of the CIAM and the emergence of dissident voices such as those of Van Eyck, Alexander, Van Lengen, Turner, Habraken or Rudofsky, who defended a less dogmatic architecture, more committed to the social community and the environment.

The successive socio-economic crisis experienced at the beginning of the 21st Century have reinvigorated this awareness, (2) generating a fragmented landscape in which various trends oppose each other, differing both in the theoretical framework used to analyze environmental problems and, in the actions, planned to address them. The set of initiatives has evolved from a generic, anthropocentric reality to a more particular 'socio-technical' concept, (3) in which technology and its impact on society weigh up. In this scenario, sustainable design leverages the indexes of what it promotes and means for society -considering that it has already acquired an environmental awareness-. The ecological conception of architecture is conditioned by two factors, which are the consequence of the balance between technical development and social consciousness: the 'pragmatic imagination' (4) which articulates the project, the work, the available means, and the community's capacity to get involved, and the responsibility and 


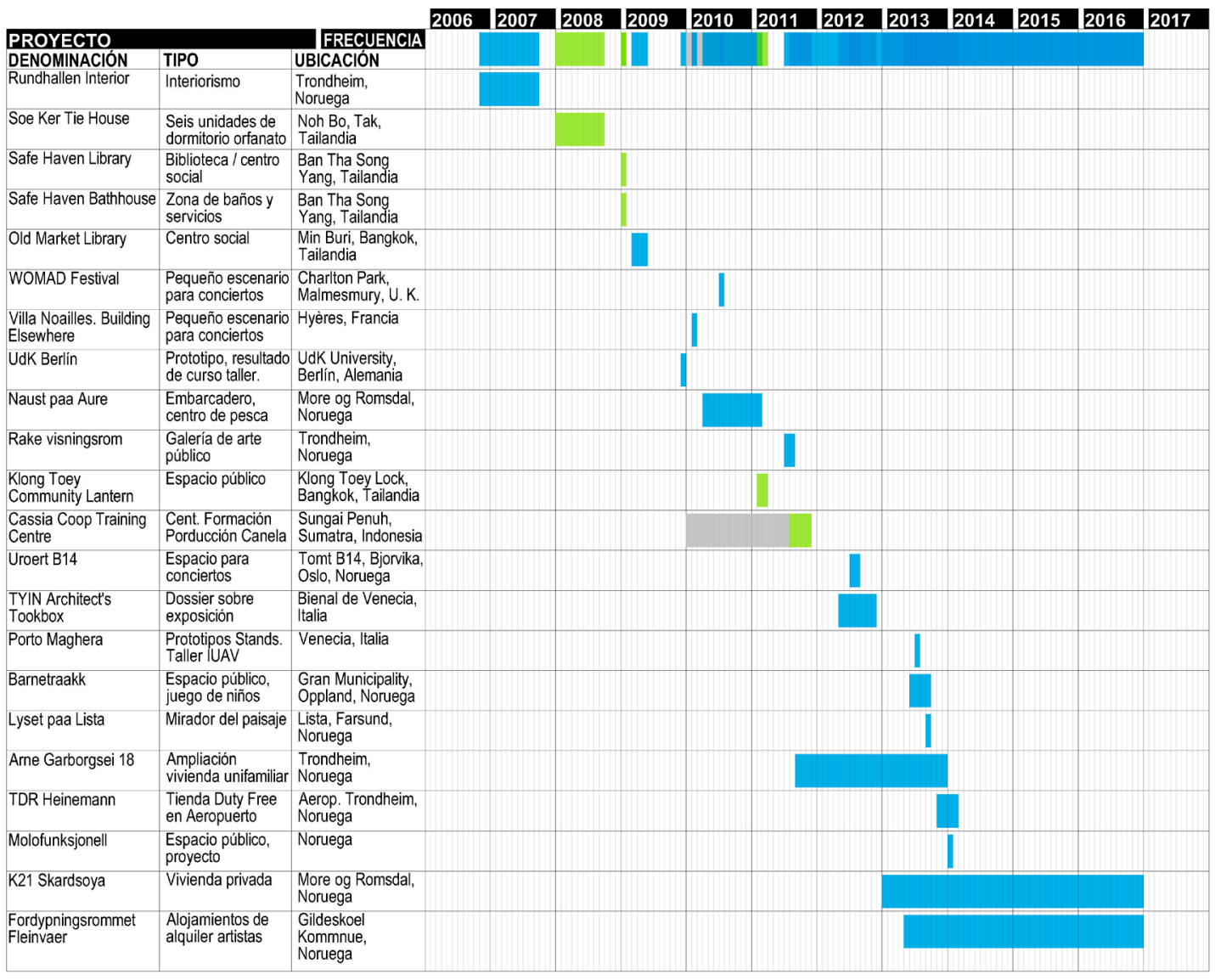

Fig. 1. Cronograma de las obras y proyectos de TYIN Tegnestue. Elaboración de los autores.

participation, conditioning the design with an ethic of doing. $(5,6)$ It has favoured the appearance of a new generation of young architects, a 'green elite', (7) situated between 'chic austerity' and 'activism', (8) and which includes names such as TYIN Tegnestue.

The main objective of this article is to deepen TYIN's work, which has had an immediate and notable impact on a global level, but which is now a concluded phenomenon. Their work, built-in different continents, participates of the project's practical and sustainable exercise, providing proportionate solutions to complex social problems without renouncing architecture's ethical and aesthetic values.

Conceptual and Operational Framework: Initial Coordinates within the Political Compass and TYIN's Toolbox. On May 26th, 2019, the components of TYIN Tegnestue, Andreas Gjertsen, and Yashar Hanstad announced their dissolution in their Facebook space. $(9,10)$ They left behind a score of twenty projects and eleven years of intense activity that began in a small office at the Norwegian University of Science and Technology (NTNU), Trondheim. (Fig. 1)

INITIAL COORDINATES. In the early years, many names played an important role that helped the young members of TYIN establish their practice's initial coordinates. These include Hans Skotte, Nabeel Hamdi, Sami Rintala, and Biver Bjarki Malmkis.

Skotte and Hamdi, lecturers on the master's program Urban Ecological Planning, $(11,12)$ provided the theoretical framework for their students' initiative Gjertsen and Hanstad. Skotte also assisted as a technical consultant. (13) Hamdi's contribu- 
una ética del hacer. $(5,6)$ Lo que ha favorecido la aparición de una nueva generación de jóvenes arquitectos, una 'élite verde', (7) que se sitúa entre la 'austeridad chic' y el 'activismo', (8) y en la que figuran nombres como TYIN Tegnestue.

Este artículo tiene como principal objetivo profundizar en el trabajo de este despacho, que ha tenido una rápida y notable repercusión a nivel global pero que es ya un fenómeno concluso. Su obra, construida en diversos continentes participa del ejercicio pragmático y sostenible del proyecto, aportando soluciones proporcionadas a problemas sociales complejos, sin renunciar a los valores éticos y estéticos de la arquitectura.

Marco operativo conceptual: coordenadas iniciales, dentro de la brújula política y una caja de herramientas. El 26 de mayo de 2019, los componentes de TYIN Tegnestue, Andreas Gjertsen y Yashar Hanstad anunciaron su disolución en su espacio de Facebook. $(9,10)$ Tras una veintena de proyectos realizados y once años de una intensa actividad que se inició en un pequeño despacho de la Norwegian University of Science and Technology (NTNU), de Trondheim. (Fig. 1)

COORDENADAS INICIALES. En los primeros años juegan un importante papel una serie de nombres que ayudaron a los jóvenes integrantes de TYIN a establecer las coordenadas iniciales de su práctica. Entre ellos, Hans Skotte, Nabeel Hamdi, Sami Rintala y Biver Bjarki Malmkis.

Skotte y Hamdi, profesores de programa de máster Urban Ecological Planning, $(11,12)$ contribuyen a establecer el marco teórico de la iniciativa de sus alumnos Gjertsen y Hanstad. Skotte asiste, además, como consultor técnico. (13) Las aportaciones de Hamdi, inciden en el valor de la improvisación y la capacidad de las actuaciones de pequeña escala para generar cambios incrementales en la comunidad. Es autor de textos como Housing without Houses, (14) Small Change: About the Art of

tions emphasized the value of improvisation and the capacity of small-scale performances to generate incremental changes in the community. He is the author of reference texts such as Housing without Houses, (14) Small Change: About the Art of Practice and the Limits of Planning in Cities, or The Spacemaker's Guide to Big Change: Design and Improvisation in Development Practice. (15) He represents the intellectual connection between TYIN and the concerns that preoccupied architects in the 1960s and 1970s. His reflection on the role of the inhabitant in the construction of their own habitat and the influence that an external agent must exert on the community to catalyze the planning and construction process in a nonalienating way has a background in Habraken's 'theory of supports', with whom he shared teaching at MIT -between 1981 and 1990-, also coinciding with John Turner. (16) [see 11]

The Finnish artist and architect Sami Rintala, (17) who uses artisan manufacturing methodologies applied in teaching seminars on a scale of 1: 1, gives TYIN a critical understanding of ecological architecture from poetic links between the place and the built object, allowing in the project a narrative dimension. It is evident in Rintala's proposal with Casagrande Land(e)scape from 1998, which had significant international repercussions, or the one presented at the Venice Biennale in 2000, Less Aesthetics, More Ethics, (18) whose title was 'Sixty-minute Man', which proposed a critical and poetic reflection on waste, its transport, and recycling.

Malmkis, a renowned Norwegian architecture critic, editor of the magazine Arkitektur $N$ until 2017, is a mentor and a disseminator of TYIN's work. His interest in reviving Kenneth Frampton's ideas of 'critical regionalism' through the filter of ecological architecture and respect for the vernacular environment coincides with the young architects' interests. (19) 
Practice and the Limits of Planning in Cities o The Spacemaker's Guide to Big Change: Design and Improvisation in Development Practice. (15) Representa la conexión intelectual entre TYIN y las inquietudes que preocuparon en la década de los 60 y 70 del siglo pasado. Su reflexión sobre el papel del habitante en la construcción de su propio hábitat y la influencia que debe ejercer un agente exterior a la comunidad para catalizar el proceso de planificación y construcción de forma no alienante, tienen un antecedente en 'la teoría de los soportes' de Habraken, con quien compartió docencia en el MIT -entre 1981 y 1990-, coincidiendo también con John Turner. (16) [ver 11]

El artista y arquitecto finlandés Sami Rintala, (17) quien emplea metodologías de fabricación artesanal, aplicadas en seminarios docentes, a escala 1:1, aporta a TYIN una comprensión crítica de la arquitectura ecológica, con la que produce vínculos poéticos entre el lugar y el objeto construido, aportando al proyecto una dimensión narrativa que puede apreciarse en la propuesta de Rintala con Casagrande Land(e)scape del año 1998, que tuvo una gran repercusión internacional, o la presentada en la Bienal de Venecia en el año 2000, Less Aesthetics, More Ethics, (18) cuyo título era 'Sixty Minute Man', con la que se proponía una reflexión crítica y poética sobre el residuo, su transporte, y reciclaje.

Malmkis, un reconocido crítico noruego de arquitectura, editor de la revista Arkitektur $N$ hasta 2017, es mentor y divulgador de la obra de TYIN. Su interés por reactivar las ideas de Kenneth Frampton del 'regionalismo crítico' desde el filtro de la arquitectura ecológica y el respeto por el medioambiente hasta lo vernáculo, coincide con los intereses de los jóvenes arquitectos. (19)

DENTRO DE LA BRÚuUla política. En el año 2017, cuando el fenómeno TYIN había alcanzado repercusión y reconocimiento, Zaera Polo y Fernández-Abascal incluyen al equipo noruego en su 'brújula política de la arquitectura emergente'. [ver 8] Un diagrama circular que sitúa y
Fig. 2. Brújula de arquitectura y política. Gráfico por Alejandro Zaera y Guillermo Fernández-Abascal. Disponible en: https:// www.plataformaarquitectura.cl/cl/802305/ la-brujula-politica-de-la-arquitectura-unataxonomia-de-la-arquitectura-emergente-enun-diagrama/5853c564e58ecebf57000221-architectures-political-compass-a-taxonomy-ofemerging-architecture-in-one-diagram-photo
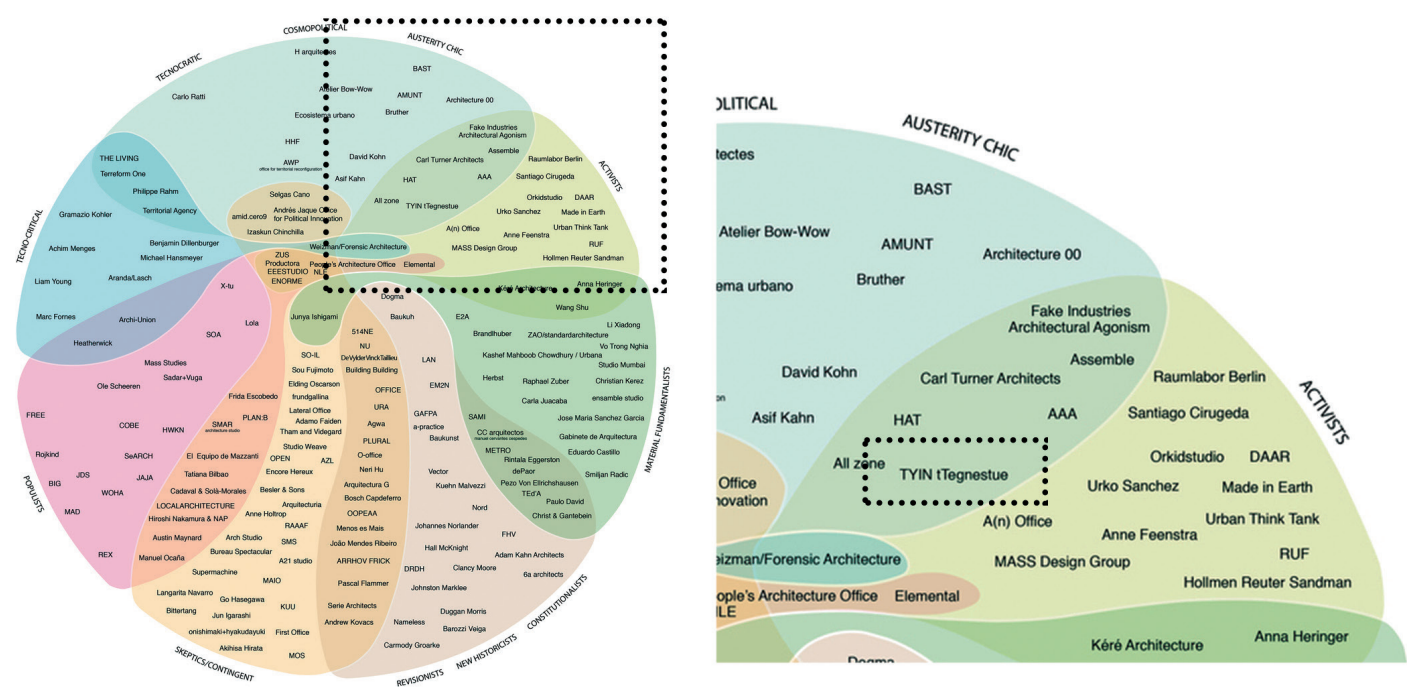
enfatiza las relaciones, intersecciones, y oposiciones de las distintas tendencias y despachos después de haberles entrevistado. (Fig. 2)

El lugar ocupado por TYIN se sitúa en la intersección de dos de las once categorías políticas contempladas, entre la 'Austeridad Chic' y el 'Activismo'. En una región compartida con Carl Turner, Fake Industries Architectural Agonism, Assemble, AAA, HAT, y all(zone), entre otros despachos emergentes. El espacio ocupado por TYIN se localiza próximo al centro del compás, lo que indica que su práctica admite, deliberadamente, la influencia de otras categorías. En este sentido, se pueden citar tres rasgos que permiten vincular a TYIN con las contiguas de los 'Fundamentalistas Materiales' y los 'Cosmopolitas': la nueva artesanía, la arquitectura como ecosistema, y el valor de lo natural frente al objeto técnico.

TYIN pone en valor el hacer artesano y participativo, identificándolo con una ética de trabajo que reconoce el diseño como un proceso coordinado por mediadores de los recursos disponibles. Para ello, en sus proyectos en Tailandia, busca el apoyo de Case Studio Architects, y en Noruega incorporan un equipo de consultores externos identificados en su página web como 'Los amigos de TYIN'. El proyecto - definido como la yuxtaposición necesaria de un diseño democrático y el respeto por la bella imperfección de los errores que surgen en el proceso de la realización de cada obra- se desarrolla entre el plan de los arquitectos y los sistemas participativos y cooperativos que cada comunidad aporta, (20) con el equilibrio entre la acción y la improvisación. (21)

Como referentes internacionales de esta manera de proyectar y construir se debe citar a Anna Heringer, Francis Keré y Studio Mumbai. Con la primera llegaron, incluso, a compartir espacio en la exposición TYIN + ANNA HERINGER Building Elsewhere. [ver 10] (Fig. 3)

También participan del entendimiento de la obra como ecosistema, en el que se construye lo imprescindible con la máxima economía, y en la
Fig. 3. Páginas extraídas del informe sobre de análisis previo a la construcción de la Biblioteca del Viejo Mercado de la Comunidad de Min Buri en Tailandia. Disponible en: http://www. tyinarchitects.com/

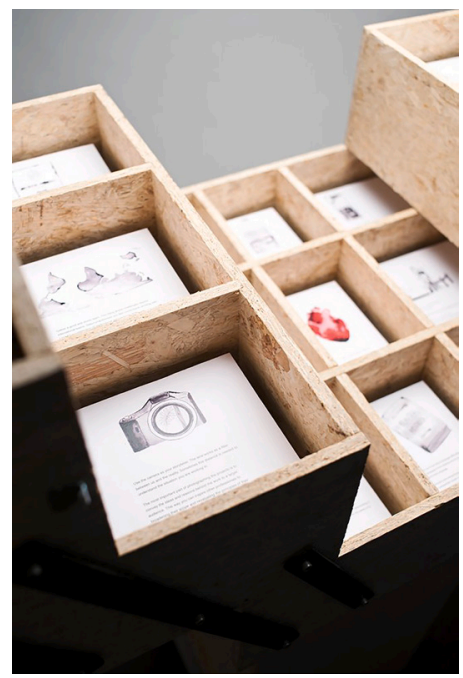

Location within the Political Compass. In 2017, when the TYIN phenomenon had achieved repercussion and recognition, Zaera Polo and Fernández-Abascal included the Norwegian team in their 'political compass of emerging architecture'. [see 8] A pie chart that situates and emphasizes the relationships, intersections, and oppositions of the various current trends and architecture offices after interviewing them. (Fig. 2)

The place occupied by TYIN appears at the intersection of two of the eleven political categories contemplated, between 'Austerity Chic' and 'Activism. A region shared with Carl Turner, Fake Industries Architectural Agonism, Assemble, AAA, HAT, and all(zone), among other emerging firms. TYIN is located near the center of the compass, indicating that its practice deliberately admits the influence of other categories. In this sense, three features allow to relate TYIN with the contiguous categories called 'Material Fundamentalists' and 'Cosmopolitans': the new craftsmanship, the architecture as an ecosystem, and its natural value opposed to a technical object.

TYIN values craftsmanship and participation, identifying it with a work ethic that recognizes design as a process coordinated by mediators of available resources. To this end, in their projects in Thailand, they sought the support of Case Studio Architects, and, in Norway, they incorporated a team of external consultants identified on their website as 'The Friends of TYIN. The project thrives between the architects' plan and the participatory and cooperative systems that each community contributes, (20) -they define it as the necessary juxtaposition of a democratic design and respect for the beautiful imperfection of the errors that arise in the process of carrying out each work-, with a balance between action and improvisation. (21) 
que el habitante desempeña un papel primordial. La estructura y cerramiento adquieren un valor esencial que remite a la diferenciación entre soporte y relleno de Habraken, y a sus implicaciones conceptuales.

El entendimiento de la arquitectura que practica TYIN, más como 'cosa' -natural- que como 'objeto' -funcional-, (22) también está presente en propuestas de otros arquitectos de la misma generación, como 'Conceptual and critical view to the resilience of architecture' de Juaçaba y Cidade -en la que se hace un ejercicio de reensamblaje de la fachada-, (23) en el trabajo de Bruder, all(zone) architects -Act naturally, Material from natu$r e-$, en la 'slow architecture' de Anne Fenstra, y en los reciclajes urbanos de Turner Architects.

UNA CAJA DE HERRAMIENTAS. Todo ello queda implícitamente recogido en lo que los arquitectos denominaron TYIN Architect's Toolbox. Un manifies-
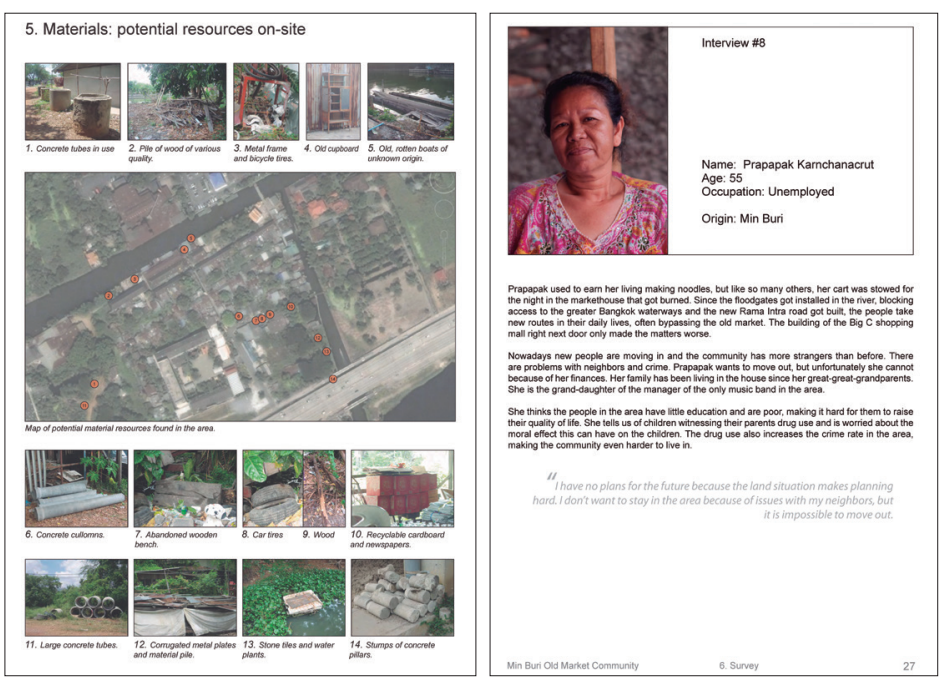

Fig. 4. Fotografía de la TYIN Architect's Toolbox. tal y como se presentó a la Bienal de Venecia de 2012. Disponible en: https:// www.archdaily.com/266246/venice-biennale2012-nordic-pavilion

Anna Heringer, Francis Keré, and Studio Mumbai are acknowledged international references for designing and building in the same trend. The former even shared space in the exhibition TYIN + ANNA HERINGER Building Elsewhere. [see 10] (Fig. 3)

They also participate in the understanding of the construction as an ecosystem. Where the essential prompts maximum economy and the inhabitant plays a primordial role. The structure and enclosure acquire a critical value referring to the differentiation between Habraken's support and filling and its conceptual implications.

TYIN's understanding of architecture considers it 'things' as natural entities rather than functional 'objects'. (22) This point of view is present in other architects of the same generation, such as in Juaçba and Cidade's 'Conceptual and critical view to the resilence of architecture' -in which an exercise in reassembling the facade is comprehensive-, (23) in Bruder's work, all(zone) architects -Act Naturally, Material from Nature-, in Anne Fenstra's 'slow architecture', and in Turner Architects' urban recycling.

A тооцвох. All this implicitly reflects on what the architects called TYIN Architect's toolbox. A manifesto, presented at the Venice Biennale in 2012, (Fig. 4) consisting of a series of illustrations -by Mio Oribe Ueno Stuberg- accompanied by direct instructions for the project and the construction. (24)

According to the architects, three types of tools can be distinguished: the 'hand' tools, useful for their very instrumental nature; the 'abstract' ones, designed to face social or mental challenges, and the 'practical advice' tools. However, behind this 


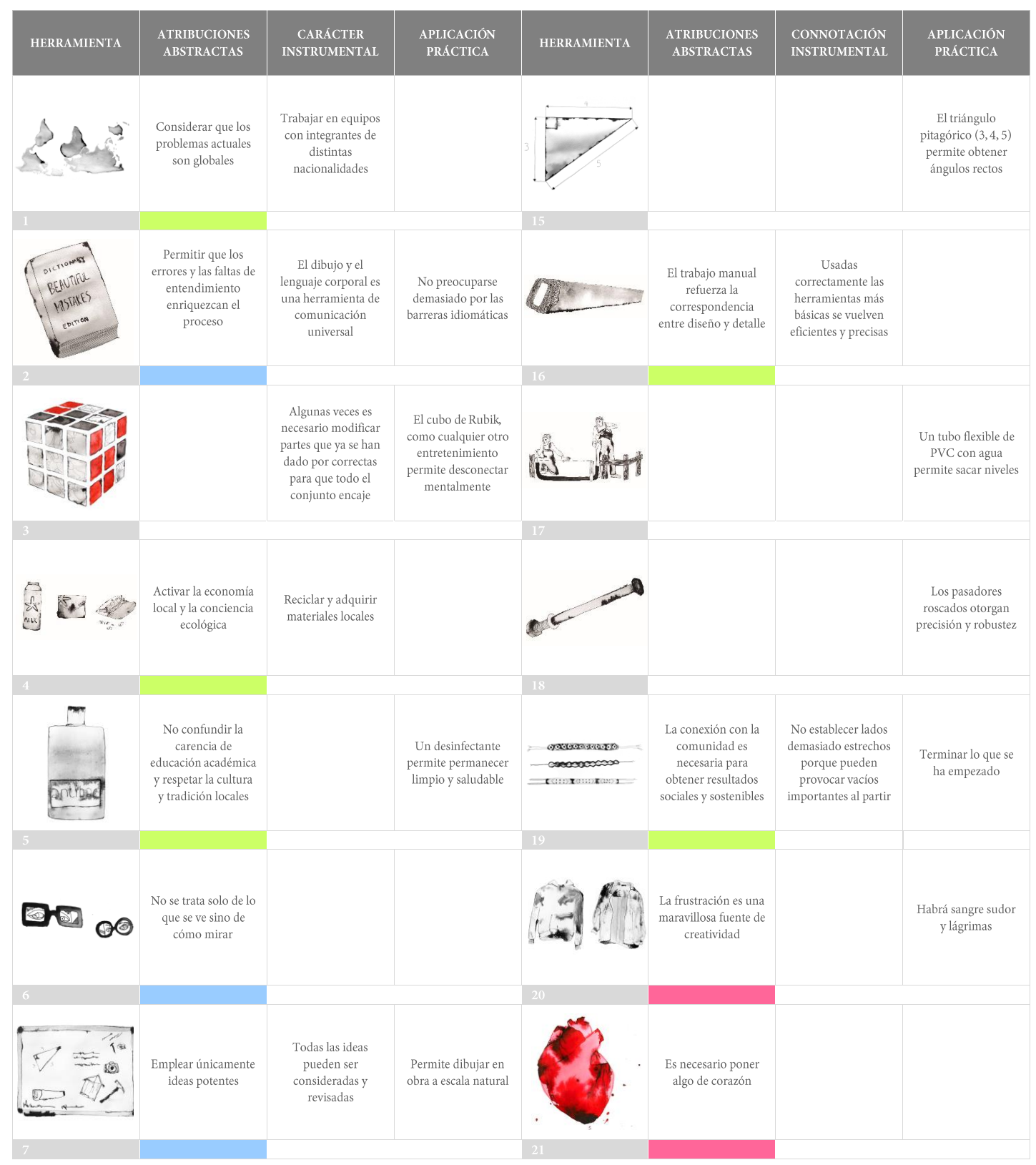




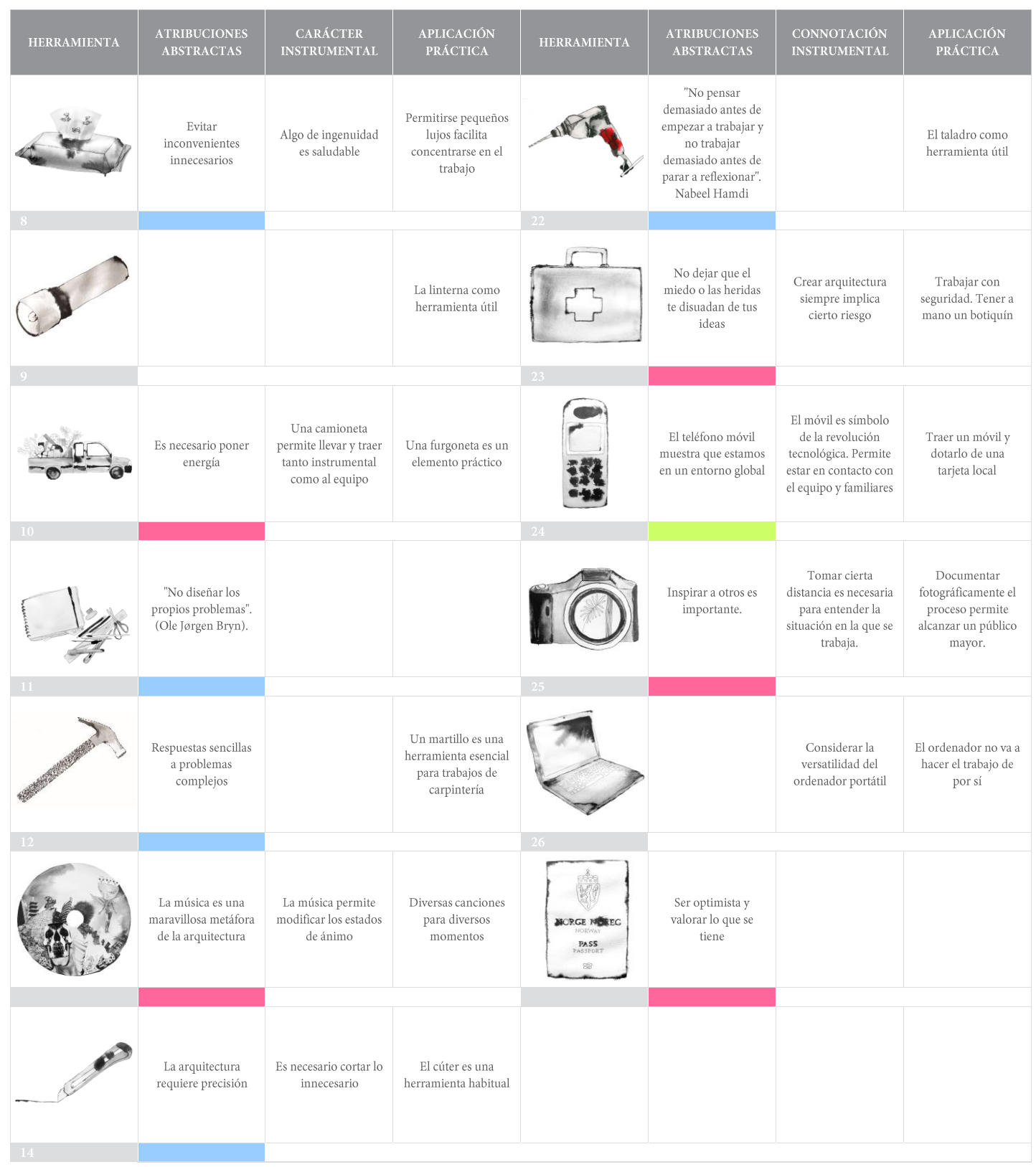

Leyenda

Atribuciones abstractas de las herramientas con carácter genérico

Atribuciones abstractas de las herramientas con carácter social y medioambiental

Atribuciones abstractas de las herramientas relacionadas con la emoción

Fig. 5. Tabla clasificatoria de las herramientas de TYIN. Elaboración de los autores. 
to, presentado en la Bienal de Venecia de 2012, (Fig. 4) consistente en una serie de ilustraciones - realizadas por Mio Oribe Ueno Stuberg- acompañadas de consignas directas para la realización del proyecto y la obra. (24)

Según indican los arquitectos, se pueden distinguir tres tipos de herramientas, las 'de mano', útiles por su mero carácter instrumental; las 'abstractas', pensadas para afrontar retos sociales o mentales, y los 'consejos prácticos'. Sin embargo, tras esta diferenciación operativa que, pese a todo, resulta ser tácita, subyace una intencionalidad. Si bien resulta evidente el carácter abstracto de algunas herramientas, otras se vinculan con la conciencia medioambiental, (Fig. 5) y otras tienen carácter afectivo -como el corazón-, que compromete emocionalmente a los habitantes y a los arquitectos. [ver 5]

Otro rasgo característico de este manifiesto es que proclama una arquitectura que se realiza con la voluntad de que sea imitada, e 'inspirar a otros', no solo desde el resultado, sino también con la dinámica de proceso, cuyos dibujos, (Figs. 6 y 7) incluso los más esquemáticos, se difunden sin restricciones. La 'cámara fotográfica' y el 'diccionario de errores’ sintetizan gráficamente esta idea.

Huellas construidas de una dinámica secuencial: un ámbito para la acción y otro para la improvisación en el proceso de TYIN. Hans Skotte y Einar Biarki Malmquist coinciden en señalar que la frase de Hamdi citada en su Toolbox: "Don't think too much before you start working; and don't work too much before you stop and start to reflect" [ver 15] sintetiza su forma de trabajar. Su paralelismo implica una alternancia temporal de periodos en los que se actúa con un plan predeterminado, y otros en los que se improvisa o experimenta, (25) se expresa en la estructura y el cerramiento.

LA ESTRUCTURA PORTANTE, Un ÁMbito PARA LA ACCión. En la mayoría de los proyectos analizados, el sistema portante es similar: constituido
Figs. 6 y 7. Croquis correspondientes a distintas fases de diversos proyectos de TYIN Tegnestue. De izquieda a derecha y de arriba abajo: Soe Ker Tie House, Safe Haven Library / Caissia Coop Training Centre, Barnetraakk / Fordypningsromeet Fleinvaer. Disponible en: www.tyinarchitects.com/
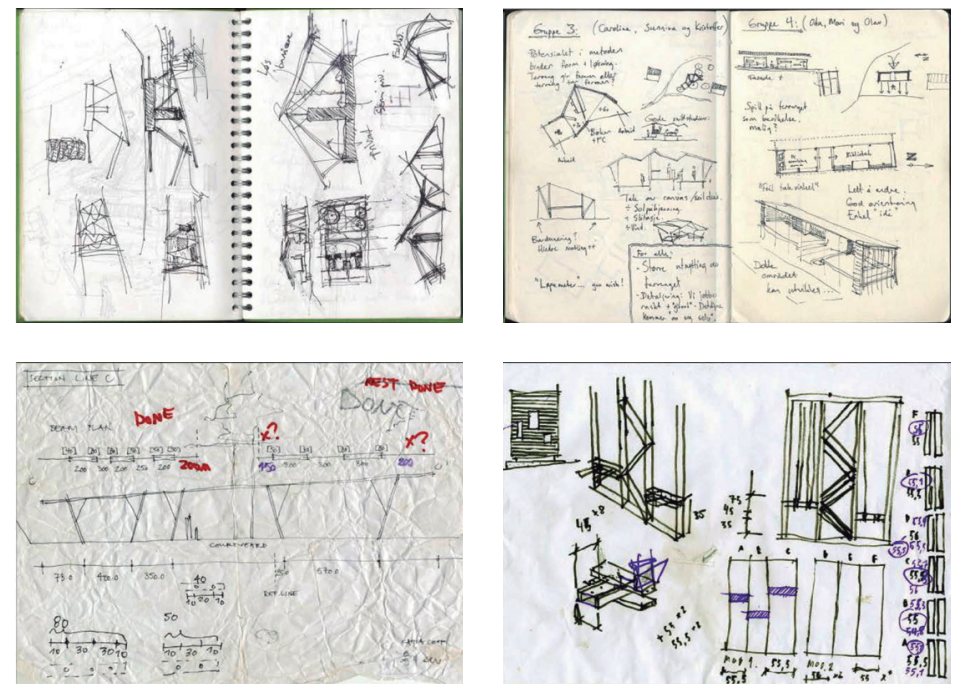

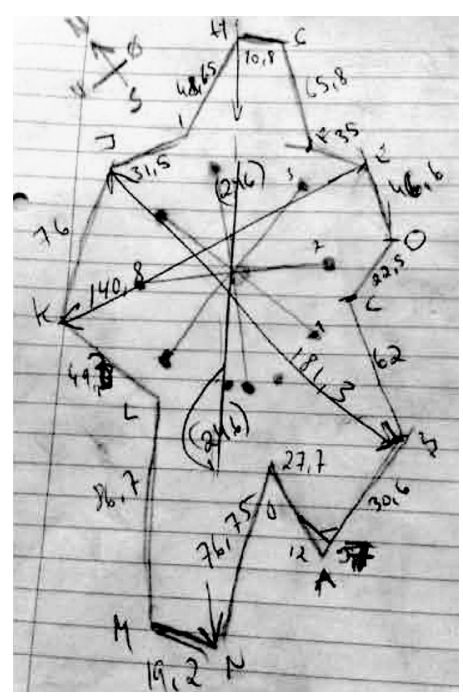



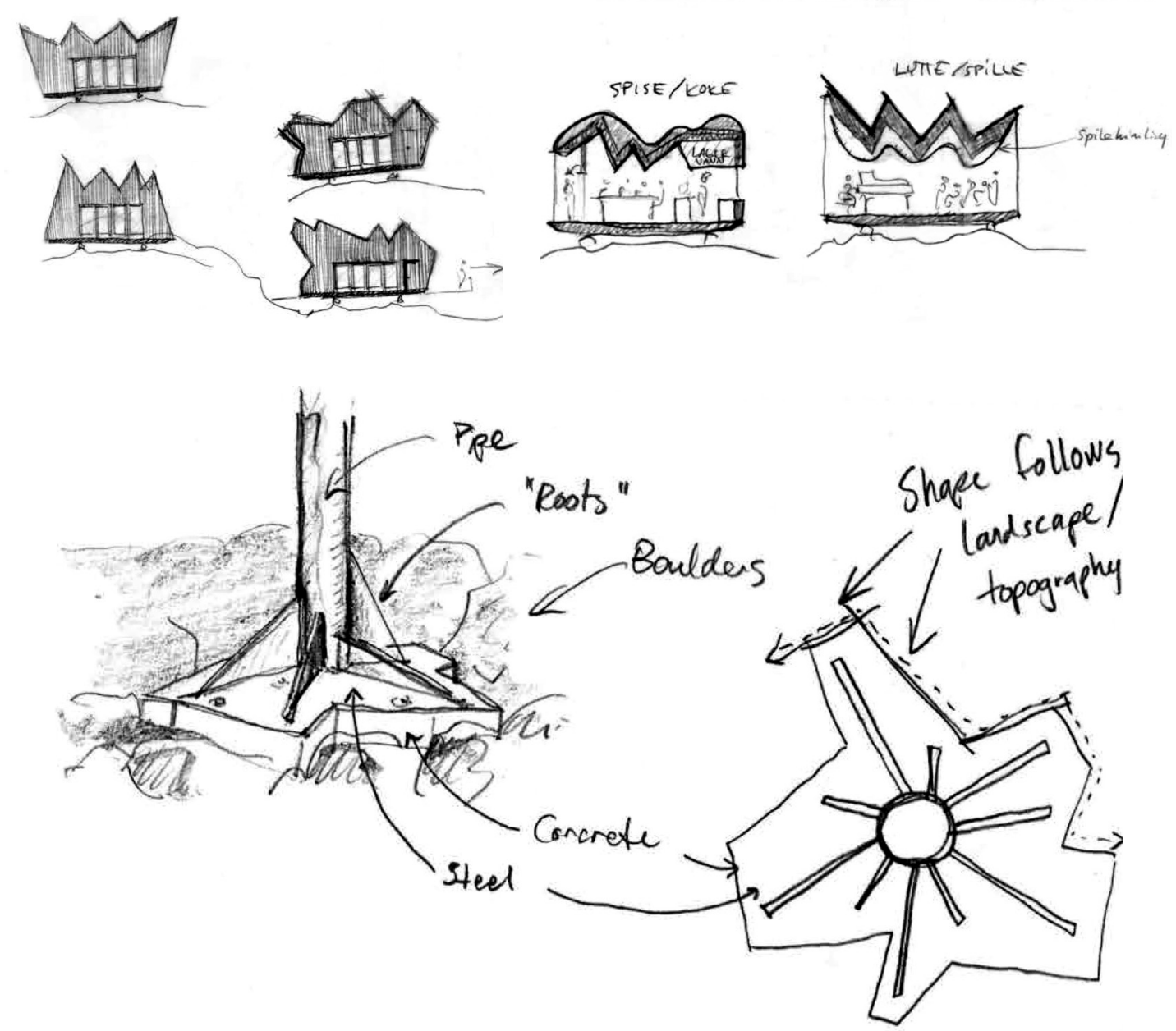

functional differentiation, that turns out to be tacit, lies an intentionality driven manner of performing. Some of the tools obviously refer to abstraction, but others link to environmental awareness, (Fig. 5) and others are emotional -like the heart-, which sensitively engages the inhabitants and the architects. [see 5]

Another characteristic feature of the manifesto is that it asserts an architecture made with the will to be imitated, and 'inspire others', not only from the result but also from the process dynamics, whose drawings, (Figs. 6 and 7) even the most schematic ones, disseminate the intention without restrictions. The 'camera' and the 'dictionary of errors' graphically synthesize this idea.

Footprints of a Sequential Dynamic: One Area for Action and another for Improvisation in the TYIN Process. Hans Skotte and Einar Biarki Malmquist agree that Hamdi's phrase quoted in TYIN's Toolbox: "Don't think too much before you start working; and don't work too much before you stop and start to reflect" [see 15] summarizes their way of working. Its parallelism implies a temporal alternation of periods in which one acts with a predetermined plan, and others in which one improvises or experiments, (25) is expressed in the structure and the enclosure.

THE BEARING STRUCTURE IS AN ACTION TOOL. In most of the analyzed projects, the bearing system is similar: made up of a set of wooden porticoes, equidistant from each other, although the shape varies from one project to another. (Fig. 8) 


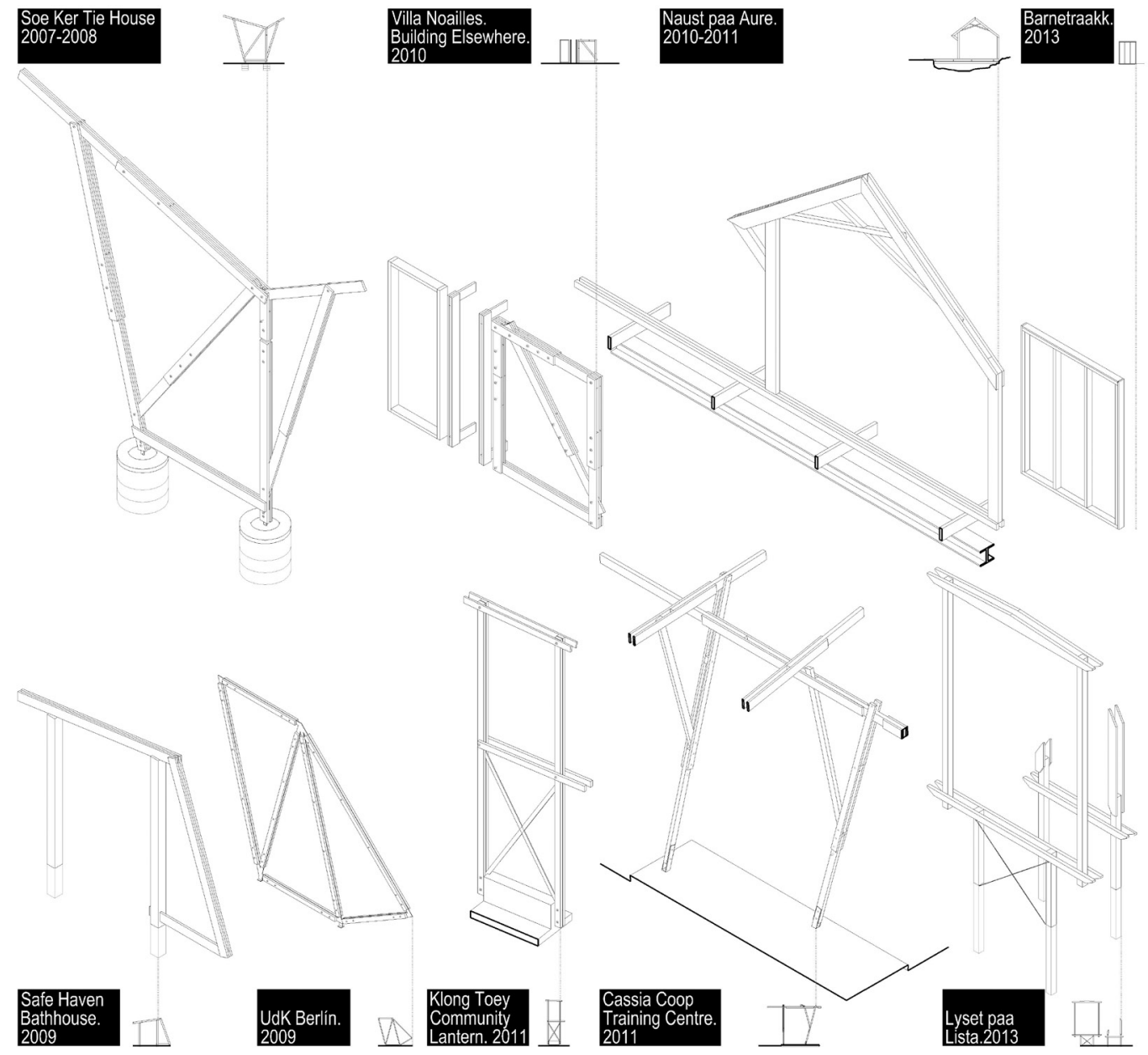

However, on a smaller scale, the detail reveals that the way they are built, with wooden planks of rectangular section is, in essence, always the same. The planks' laid out in parallel, interspersed with spacings that allow slots for the joints between the beams, the pillars, the bracing, and the foundations. The threaded pins, another of the prescribed 'tools', are 'more precise and solid than nails' when reinforced plates secure the joints. (Fig. 9)

The analogous solution in various projects reveals how the structure catalyzes construction, ensuring fast, direct and straightforward execution. One of their first works, the Soe Ker Tie House, shows it bluntly. Other later projects in Thailand, Indonesia, and Norway maintain this bearing system pattern until it becomes an identifying feature of their architecture.

THE ENCLOSURE IS A SUBJECTIVE ENVIRONMENT FOR IMPRovisATion. Similarly, the moment for 'improvisation' [see 15] -is the term proposed by Hamdi in the already mentioned text 'The Spacemaker's Guide to Big Change: Design and Improvisation in Development Practice'- arises with the construction of the enclosure. This expressive and subjective limit makes visible, more than the structure, the links with the community, and the context. In some cases, they resort to materials derived from primary industrial processes -always economical and accessible-, as is the case with the mortar block used in Safe Haven. In others, they are recycled or raw. The chosen are those whose handling and application are available by local artisans who are familiar with them. In the Noh Bo orphanage's dormitories, they anticipate a line of research to which they will return later. A good part of the enclosure of this building has a single material: bamboo trunks. Manipulating them and arranging them in diverse forms, they obtain multiple shades as much in the interior as in the 
por un conjunto de pórticos de madera, equidistantes entre sí. El marco formal varía de unos proyectos a otros. (Fig. 8)

Pero a menor escala, el detalle revela que la forma de construirlos, con tablones de madera de sección rectangular es, en esencia, siempre la misma. Los tablones se disponen paralelamente, intercalando separaciones que permiten las uniones entre las vigas, los pilares, los arriostramientos y la cimentación. Los pasadores roscados, otra de las 'herramientas' prescritas, son 'más precisos y sólidos que los clavos', y al reforzarse con chapas aseguran las uniones. (Fig. 9)

La solución análoga en los diversos proyectos revela cómo la estructura cataliza el inicio de la construcción, asegurándose la ejecución rápida, directa y sencilla. Uno de sus primeros proyectos, la Soe Ker Tie House, lo muestra con claridad. Otros posteriores, ubicados en Tailandia, en Indonesia, y en Noruega, mantienen este sistema de soportes hasta convertirlo en una característica identitaria de su arquitectura.

el Cerramiento, un ámbito subjetivo para la improvisación. De forma análoga, el momento para la 'improvisación' [ver 15] -término propuesto por Hamdi en el texto The Spacemaker's Guide to Big Change: Design and Improvisation in Development Practice- surge con la construcción del cerramiento. Este límite expresivo y subjetivo hace visible, más que la estructura, los lazos con la comunidad, y el contexto. En algunos casos, recurren a materiales derivados de procesos industriales primarios, -siempre económicos y accesibles-, como sucede con el bloque de mortero empleado en Safe Haven. En otros, reciclados o en bruto. Se eligen aquellos en cuya manipulación y puesta en obra puedan intervenir los artesanos locales familiarizados con ellos. En los dormitorios del orfanato de Noh Bo, anticipan una línea de investigación sobre la que volverán posteriormente. Buena parte del cerramiento de este edificio se realiza con un único material: troncos de bambú. Manipulándolos y disponiéndolos de formas diversas, consiguen múltiples matices tanto
Fig. 8. Resumen de los pórticos estructurales empleados por TYIN Tegnestue en distintos proyectos. Todos ellos están realizados con tablones de madera y con un sistema similar. Elaboración de los autores.

Fig. 9. Detalles constructivos de las uniones de los pórticos del orfanato Soe Ker Tie House, en Noh Bo. Elaboración de los autores.

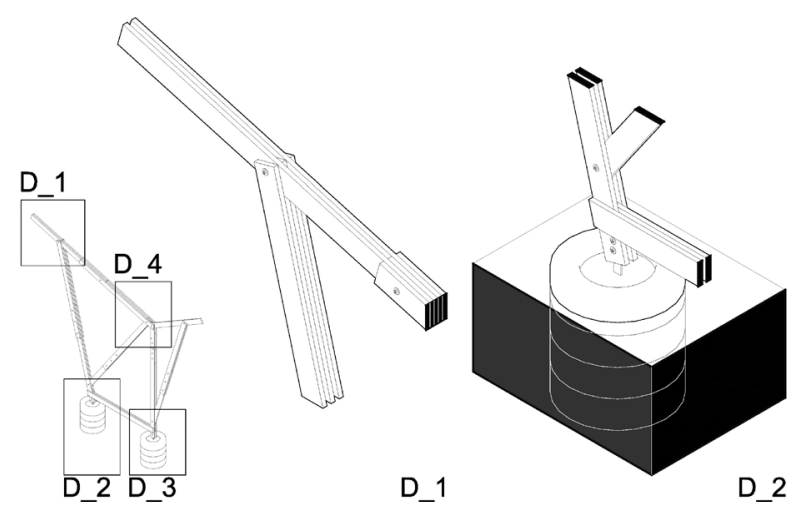

D_2
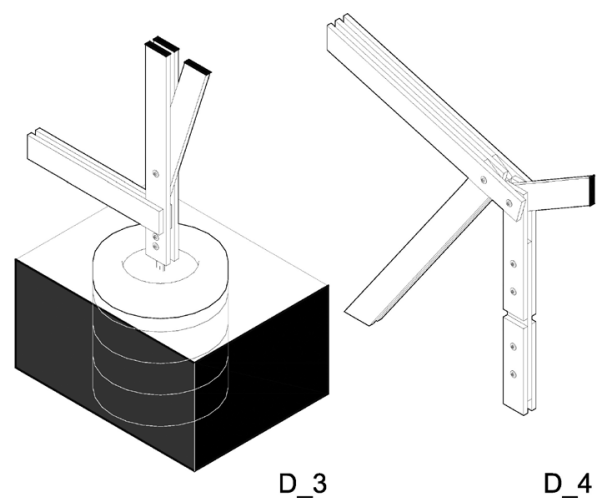
en el interior como en el exterior. En algunas zonas se emplean las cañas cortadas longitudinalmente en franjas largas y estrechas, disponiéndose un filtro textil; en otras, enterizas y paralelas, construyendo cerramientos más rígidos, marquesinas que protegen del sol, incluso columpios. Y con el mismo material, celosías, al cortar las cañas transversalmente en segmentos de escasa longitud. (Fig. 10)

En el Centro de Formación Cassia Coop, uno de sus edificios más complejos, reaparecen algunas de estas exploraciones. Dado que en Sungai Penuh, se produce el $85 \%$ de la canela del mundo, sustituyen el bambú por troncos
Fig. 10. Tabla con fotografías de diversas obras de TYIN Tegnestue mostrando diversas estrategias en la conformación de los cerramientos. Fotografías de Paisi Aalto.

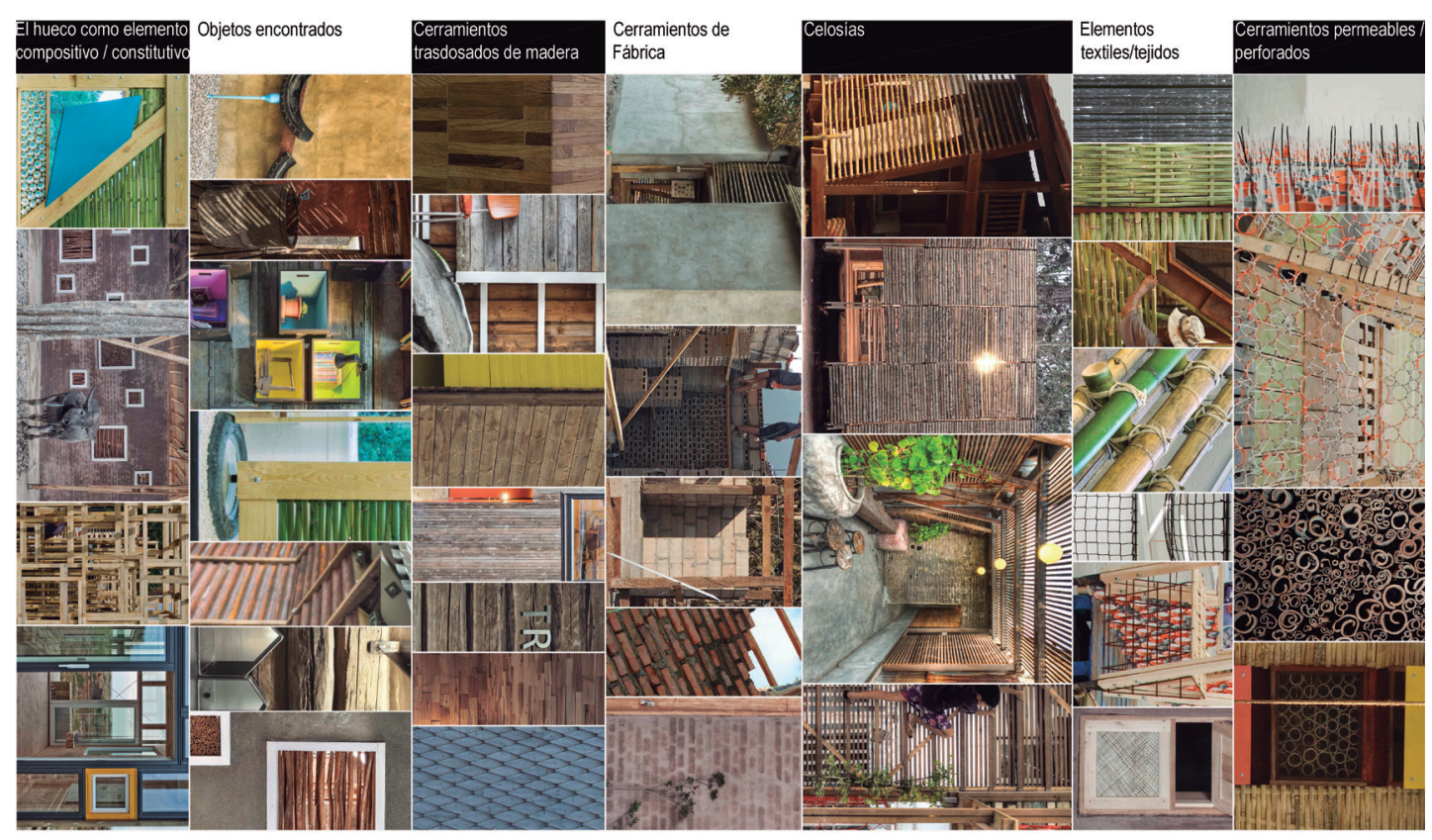

outside. In some zones the canes cut longitudinally in long and narrow strips are used, arranging a textile filter; in others, whole and parallel, constructing more rigid closings, canopies that protect from the sun, even swings. Moreover, with the same material, lattices, by cutting the canes transversally into short length. (Fig. 10)

In the Cassia Coop Training Centre, one of its most elaborate buildings, some of these explorations reappear. As in Sungai Penuh $85 \%$ of the world's cinnamon sorts, they substitute the bamboo by trunks and barks of the cinnamon, by-products of the processing the cinnamon. They design elements that sieve the light through the holes cut randomly in local and artisan brick walls. The choice of materials -scarcely treated or recycled-reveals the determination to build with reduced resources, decreasing the carbon footprint.

When these architects work in more developed areas, such as in Norway, they do not give up this ethic. It is the Naas paa Aure Kommune landing house or the Duty-Free shop at Trondheim Airport. Far from falling into a convention, they strive to use recycled materials from abandoned local buildings. It also allows them to establish a sensitive narrative with the vernacular memory, finding an apparent reference in Sami Rintala's projects. (26)

The free and spontaneous form with which the facades' gaps are eventually placed with irregular rhythms underlines each element's versatile character within the whole. It is the case of the Cassia Training Centre or the Lyset Paa Lista Landscape Interpretation Centre. The facades are a collage of recycled windows. In other projects, we can see the will to build more 
y cortezas del canelo, subproductos del procesado de la canela. Con ellos proyectan elementos que tamizan la luz a través de los huecos recortados aleatoriamente en los muros de ladrillo local y artesanal. La elección de materiales -escasamente tratados, o reciclados- revela la determinación de construir con recursos reducidos, disminuyendo la huella de carbono.

Cuando los arquitectos trabajan en otras zonas más desarrolladas, como en Noruega, no renuncian a esta ética. Es el caso de la casa-embarcadero de Naas paa Aure Kommune o la tienda del Duty Free del Aeropuerto de Trondheim, lejos de caer en convencionalismos, se esfuerzan por emplear materiales reciclados, que provienen de construcciones locales abandonadas. Esto les permite, además, establecer una narrativa sensible con la memoria del lugar, con lo vernáculo, encontrando un claro referente en los proyectos de Sami Rintala. (26)

La forma libre y espontánea con la que eventualmente se sitúan los huecos en las fachadas con ritmos irregulares subraya el carácter versátil de cada elemento dentro del conjunto. Es el caso del Centro de Formación de Cassia o del Centro de Interpretación del Paisaje de Lyset Paa Lista. Las fachadas son un collage de ventanas recicladas. En otros proyectos se advierte la voluntad de construir más con 'objetos encontrados', versátiles y elocuentes, que con funcionales 'objetos tipo'. Esto sucede en la casa de baños de Safe Haven, en la que unos neumáticos usados y seccionados se convierten en urinarios, mientras que en el orfanato de Noh Bo, sirven de encofrado para la cimentación. En la Biblioteca del Viejo Mercado de Min Buri, las cajas de madera para el almacenaje y transporte de alimentos se reutilizan en las estanterías de la biblioteca, y en las lámparas que, además de iluminar el espacio interior, aportan una 'optimista' nota de color. Su azarosa posición en el muro evoca, anticipadamente, espontaneidad con la que se define el hueco.

Conclusiones. El análisis crítico del trabajo de TYIN y el estudio de sus proyectos y las herramientas utilizadas, permite obtener algunas conclusiones reunidas en los siguientes apartados:

with 'found objects', versatile and eloquent, than with functional 'type objects'. The case at the Safe Haven bathhouse, where used and sectioned tires became urinals, while at the Noh Bo orphanage, they serve as formwork for the foundations. In the Old Market Library in Min Buri, wooden boxes for storing and transporting food are reused on the library shelves and in the lamps, which, in addition to illuminating the interior space, provide an 'optimistic' note of color. Their random position on the wall evokes, in advance, the spontaneity with which space place.

Conclusions. The critical analysis of TYIN's work and the study of their projects and the tools used allows some conclusions drawn from the following sections:

THEORY IN PRACTICE AND PRACTICE IN THEORY. Although they have a pre-established theoretical framework, they do not make it visible. They rely more on the set of tools - Toolbox - to use in the development of each project and work. The analysis carried out reveals that those 'tools', even though they split into operational categories, refer in a veiled way to the ethics and the theoretical framework of each project.

manufacturing versus prefabrication. Prefabrication implies a process of decontextualization, in which the matter and the natural objects reconstitute as technical for a practical and quantitative application besides the detriment of their qualitative value. (27) Contemporary architects have progressively assumed that all technologies are neutral concerning their social values. (28) TYIN's projects show a vocation opposed to decontextualization and 
TEORÍA EN LA PRÁCTICA Y PRÁCTICA EN LA TEORÍA. Si bien poseen un marco teórico preestablecido, no lo hacen visible. Confían más en el conjunto de herramientas -toolbox- que pueden utilizar en el desarrollo de cada proyecto y obra. El análisis realizado revela que estas 'herramientas', aunque se presentan divididas por categorías operativas, remiten veladamente a la ética y el marco teórico del proyecto.

MANUFACTURA VERSUS PREFABRICACión. La prefabricación, implica un proceso de descontextualización, con el que la materia y los objetos naturales, se reconstituyen como objetos técnicos, para una aplicación utilitaria y cuantitativa en detrimento de su valor cualitativo. (27) Los arquitectos contemporáneos han asumido progresivamente que todas las tecnologías son neutras con relación a sus valores sociales. (28) Los proyectos de TYIN demuestran una vocación opuesta a la descontextualización y la estandarización, tantas veces aplicadas en la arquitectura de emergencia, produciendo vínculos sociales con la manufactura, las tecnologías escaladas a las necesidades reales, y a la comprensión de las comunidades en las que trabajan. En cada uno de sus proyectos se reúnen soluciones específicas y localizadas que no son exportables a otros contextos, evitando la automatización, la estandarización y el intercambio de las soluciones de un lugar a otro. El estudio realizado demuestra que esto es más cierto en el desarrollo del cerramiento y la fachada, y es menos evidente en la estructura. En los proyectos de TYIN se pueden establecer asociaciones claras con la teoría de la instrumentalización primaria y secundaria de Feenberg; (29) en particular, con 'la vocación' (30) con la que se insiste en la importancia de la subjetividad desde la relación entre los humanos, la tecnología, las herramientas, y los artefactos.

POSICIONAMIENTO CRÍTICO CON RELACIÓN A LOS OBJETOS TÉCNICOS AUTÓNOMOs. La arquitectura de TYIN pone en valor la relación del objeto técnico con su instrumentalización social. Y a los usuarios, los convierte en 'actores' y 'agentes', trascendiendo el papel de meros receptores de la obra. (31) En este compromiso, la técnica no aparece como un elemento

standardization so often applied in emergency architecture, producing social links with manufacturing, technologies scaled to real needs and understanding the communities in which they work. In each of their projects, they bring together specific and localized solutions that not always are exportable to other contexts, avoiding automation, standardization, and exchanging solutions from one place to another. The study carried out shows that this is true in developing the enclosure and the facade and is less evident in the structure. In TYIN's projects, clear associations link with Feenberg's theory of primary and secondary instrumentalization; (29) in particular, with 'the vocation' (30) with which the importance of subjectivity hovers over the relationship between humans, technology, tools, and artifacts.

CRITICAL POSITIONING OF AUTONOMOUS TECHNiCAL OBJECTS. TYIN's architecture emphasizes the relationship between the technical object and its social instrumentalization. Moreover, users turn themselves into actors and agents, transcending the role of mere receivers of the work. (31) In this commitment, the technique does not appear as an autonomous element. However, as an essential part of the shared design, [see 4] the balance between the community and the architects is not only useful to increase the culture and learning of both with the construction, but it also incorporates the perception and needs of the users in the architecture, making it more sustainable. This strategy's success measures the ability of architects and users to harmonize technical objects as primary -with a decontextualized and autonomous value- and secondary -with their social and context-specific adaptability- instruments. 
autónomo sino como una parte esencial del diseño compartido, 'colegiado' y 'coevolucionado' con la comunidad [ver 4] Este equilibrio entre la comunidad y los arquitectos no es solo útil para incrementar la cultura y el aprendizaje de ambos con la construcción, sino que incorpora, además, la percepción y las necesidades de los usuarios en la arquitectura, haciéndola más sostenible. El éxito de esta estrategia puede medirse por la capacidad que demuestran los arquitectos y los usuarios en la armonización de los objetos técnicos como instrumentos primarios -con un valor descontextualizado y autónomo- y secundarios - con su adaptabilidad social y específica en cada contexto-.

USO DE LA ARQUITECTURA PARA PROMOVER PRÁCTICAS CONCRETAS DE RELACIÓN ENTRE LAS PARTES OBJETIVAS Y LAS SUBJETIVAS DEL DISEÑO. Uno de los objetivos de este artículo es poner en valor esta relación, demostrando la relevancia de los segundos en la obra de TYIN. Las distintas fases del diseño comprometen lo concreto y específico de cada lugar y comunidad con lo que se proyecta y construye para ella, estableciéndose una mediación crítica entre las estrategias sistemáticas y las contextuales. Otro aspecto relevante es el carácter mediador con la comunidad identificado en el proyecto arquitectónico, asociándolo con lo vernáculo. $(32,33)$ De esta manera, construir y proyectar, se asocian orgánica e indistintamente, como sucede en la arquitectura vernácula. Una relación, que en el contexto contemporáneo, promueve un nuevo concepto de artesanía (34) conectado con la fabricación y la construcción, lo que Christopher Alexander denominó con otras palabras el modo intemporal de construir o la consciencia vernácula, en el que la acción de construir puede ser constantemente redefinida. (35)

USE OF ARCHITECTURE TO PROMOTE CONCRETE PRACTICES OF THE RELATIONSHIP BETWEEN THE OBJECTIVE AND SUBJECTIVE PARTS OF THE DESIGN. One of this article's objectives is to highlight this relationship, demonstrating the relevance of the latter in TYIN's work. The design's different phases commit the concrete and specific of each place and community with design and construction, establishing a critical mediation between the systematic and the contextual strategies. Another relevant aspect is the mediating character with the community identified in the architectural project, associating it with the vernacular. $(32,33)$ In this regard, building and designing associate organically and indistinctly, as happens in the vernacular architecture. A relationship which, in the contemporary context, promotes a new concept of craftsmanship (34) connected with manufacturing and construction, what Christopher Alexander called, in other words, the timeless way of building or the vernacular consciousness, in which the action of building always updates. (35) 


\section{REFERENCIAS}

1. CRUTZEN, P.J. Geology of mankind. En: Nature [online]. 3 January 2002, vol. 415, p. 23, Disponible en: https://doi.org/10.1038/415023a 2. GUY, S.; FARMER, G. Reinterpreting sustainable architecture: the place of technology. Journal of Architectural Education [online]. 2001, vol. 54. Disponible en: https://doi.org/10.1162/10464880152632451 3. FEENBERG, A. Questioning Technology. New York, NY, USA: Routledge, 1999.

4. FARMER, G.; GUY, S. Making Morality: Sustainable Architecture and the Pragmatic Imagination. Build. Res. Inf. 2010, vol. 38, pp. 368-378. 5. GUY, S.; FARMER, G. Reinterpreting sustainable architecture: the place of technology. Journal of Architectural Education [online]. 2001, vol. 54. Disponible en: https://doi.org/10.1162/10464880152632451 6. VEAK, T. Democratizing Technology: Andrew Feenberg's Critical Theory of Technology. Albany, NY, USA: SUNY Press, 2006.

7. OWEN, C.; DOVEY, K. Fields of sustainable architecture. J. Archit. 2008, vol. 13, pp. 9-21.

8. ZAERA, A.; FERNÁNDEZ- ABASCAL, G. La brújula política de la arquitectura: una taxonomía de la arquitectura emergente en un diagrama. Disponible en: https://www.plataformaarquitectura.cl/ cl/802305/la-brujula-politica-de-la-arquitectura-una-taxonomia-de-laarquitectura-emergente-en-un-diagrama ca.2017

9. TYIN TEGNESTUE. Disponible en: https://www.facebook.com/ TYINtegnestue.

10. TEGNESTUE, T.Work. [consultado 14 de noviembre de 2019]. Disponible en: http://www.tyinarchitects.com/works/

11. HAMDI, Nabeel. Small Change: About the Art of Practice and the limits of Planning in Cities. London: Earthscan, 2004.

12. TYIN TEGNESTUE. Disponible en: https://www.ntnu.edu/studies/ courses/AAR5210\#tab=omEmnet

13. SKOTTE, H. El auge de TYIN Tegnestue. En: TYIN Tegnestue: In detail. Sabadell: Architect Publications S.L, 2016.

14. HAMDI, N. Housing WIthout Houses: Participation, Flexibility, Enablement. London: Intermediate Technology, 1995.

15. HAMDI, N. The Spacemaker's Guide to Big Change: Design and Improvisation in Development Practice. Routledge, 2014.

16. WARD, C. Foreword. En: HAMDI, N. Small Change: About the Art of Practice and the limits of Planning in Cities. London: Earthscan, 2004.

17. RINTALA, S. Edge-On Paracentric architecture. Topos, 2012, vol. 70, pp. 48-55.

18. VV AA. Città: less aesthetics more ethics. 7th International Architecture Exhibition. Venezia: Marsilio, 2000.

19. MALMQUIST, E. B. Levantando el tiempo. En TYIN Tegnestue: In detail. Sabadell: Architect Publications S.L, 2016.

20. LUCK, R. Participatory design in architectural practice: Changing practices in future making in uncertain times. Design Studies. 2018, vol. 59, pp. 139-157.

21. ZABALBESCOA, A. Los antihéroes de la nueva arquitectura [online]. Disponible en: https://elpais.com/elpais/2015/12/01/ eps/1448986169_230396.html

22. ELEMENTAL. A Thing not an Object: Primeira Pedra. [online].

[Consultado 6 December 2020]. Disponible en: http://www. primeirapedra.com/projects/a-thing-not-an-object-2/

23. JUAÇABA, C. Conceptual and critical view to the resilience of architecture [online]. [Consultado 6 December 2020]. Disponible en: https://www.carlajuacaba.com.brArchitecture.

24. TYIN TEGNESTUE. Disponible en: http://tyinworkshop2009. blogspot.com/

25. HANSTAD, Y. Democratic design and beautiful mistakes. Conferencia ofrecida en 2014, en la Universidad Politécnica de Cartagena [online], vol. 1, no. 36. Disponible en: https://www.youtube.com/watch?v=jf8n1_ p3ABk

26. RINTALA, S.; SPADONI, M. Forest Matrix. Towards Architecture for pluralism, diversity, minorities, alternatives. Ri-Vista, 2017, vol. 15, n. 1. 27. MITCHAM, C. Dasein versus Design: The Problematics of Turning Making into Thinking. Int. J. Technol. Des.Educ. 2001, vol. 11, pp. 27-36. 28. MITCHAM, C. Ethics into design. En: BUCHANAN, R.; MARGOLIN, V. Discovering Design: Explorations in Design Studies. Chicago: University of Chicago Press, 1995.

29. FEENBERG, A. Critical Theory of Technology: An Overview. Tailoring Biotechnol. 2005, vol. 1, pp. 47-64.

\section{REFERENCES}

1. CRUTZEN, P.J. Geology of mankind. In: Nature [online]. 3 January 2002, vol. 415, p. 23, Available at: https://doi.org/10.1038/415023a 2. GUY, S.; FARMER, G. Reinterpreting sustainable architecture: the place of technology. Journal of Architectural Education [online]. 2001, vol. 54. Available at: https://doi.org/10.1162/10464880152632451 3. FEENBERG, A. Questioning Technology. New York, NY, USA: Routledge, 1999.

4. FARMER, G.; GUY, S. Making Morality: Sustainable Architecture and the Pragmatic Imagination. Build. Res. Inf. 2010, vol. 38, pp. 368-378. 5. GUY, S.; FARMER, G. Reinterpreting sustainable architecture: the place of technology. Journal of Architectural Education [online]. 2001. Vol. 54. Available at: https://doi.org/10.1162/10464880152632451 6. VEAK, T. Democratizing Technology: Andrew Feenberg's Critical Theory of Technology. Albany, NY, USA: SUNY Press, 2006. 7. OWEN, C.; DOVEY, K. Fields of sustainable architecture. J. Archit. 2008, vol. 13, pp. 9-21.

8. ZAERA, A.; FERNÁNDEZ-ABASCAL, G. La brújula política de la arquitectura: una taxonomía de la arquitectura emergente en un diagrama. Available at: https://www.plataformaarquitectura.cl/ cl/802305/la-brujula-politica-de-la-arquitectura-una-taxonomia-de-laarquitectura-emergente-en-un-diagrama ca.2017

9. TYIN TEGNESTUE. Available at: https://www.facebook.com/ TYINtegnestue

10. TEGNESTUE, T. Work. [Accessed 14 November 2019]. Available at: http://www.tyinarchitects.com/works/

11. HAMDI, Nabeel. Small Change: About the Art of Practice and the Limits of Planning in Cities. London: Earthscan, 2004.

12. TYIN TEGNESTUE. Available at: https://www.ntnu.edu/studies/ courses/AAR5210\#tab=omEmnet

13. SKOTTE, $\mathrm{H}$. El auge de TYIN Tegnestue. In: TYIN Tegnestue: In detail. Sabadell: Architect Publications S.L, 2016.

14. HAMDI, N. Housing WIthout Houses: Participation, Flexibility, Enablement. London: Intermediate Technology, 1995.

15. HAMDI, N. The Spacemaker's Guide to Big Change: Design and Improvisation in Development Practice. Routledge, 2014.

16. WARD, C. Foreword. In: HAMDI, N. Small Change: About the Art of Practice and the limits of Planning in Cities. London: Earthscan, 2004.

17. RINTALA, S. Edge-On Paracentric architecture. Topos, 2012, vol. 70, pp. 48-55.

18. AA. VV. Città: less aesthetics more ethics. 7th International

Architecture Exhibition. Venezia: Marsilio, 2000.

19. MALMQUIST, E. B. Levantando el tiempo. In: TYIN Tegnestue:

In detail. Sabadell: Architect Publications S.L, 2016.

20. LUCK, R. Participatory design in architectural practice: Changing practices in future making in uncertain times. Design Studies. 2018, vol. 59, pp. 139-157.

21. ZABALBESCOA, A. Los antihéroes de la nueva arquitectura [online]. Available at: https://elpais.com/elpais/2015/12/01/ eps/1448986169_230396.html

22. ELEMENTAL. A Thing not an Object: Primeira Pedra. [online].

[Accessed 6 December 2020]. Available at: http://www.primeirapedra. com/projects/a-thing-not-an-object-2/

23. JUACABA, C. Conceptual and critical view to the resilience of architecture [online]. [Accessed 6 December 2020]. Available at: https:// www.carlajuacaba.com.brArchitecture

24. TYIN TEGNESTUE. Available at: http://tyinworkshop2009.blogspot. com/

25. HANSTAD, Y. Democratic design and beautiful mistakes. Conferencia ofrecida en 2014, en la Universidad Politécnica de Cartagena [online], vol. 1, n. 36. Available at: https://www.youtube.com/watch?v=jf8n1_ p3ABk

26. RINTALA, S.; SPADONI, M. Forest Matrix. Towards Architecture for pluralism, diversity, minorities, alternatives. Ri-Vista, 2017, vol. 15, n. 1 . 27. MITCHAM, C. Dasein versus Design: The Problematics of Turning Making into Thinking. Int. J. Technol. Des.Educ. 2001, vol. 11, pp. 27-36. 28. MITCHAM, C. Ethics into design. In: BUCHANAN, R.; MARGOLIN, V. Discovering Design: Explorations in Design Studies. Chicago: University of Chicago Press, 1995.

29. FEENBERG, A. Critical Theory of Technology: An Overview. Tailoring Biotechnol. 2005, vol. 1, pp. 47-64. 
30. FARMER, G. From Differentiation to Concretisation: Integrative Experiments in Sustainable Architecture. Societies [online]. 2017, vol. 7, n. 4, p. 35. Disponible en: https://search.proquest.com/docview/1988504 611 ? accountid $=14712$

31. RORTY, R. Achieving Our Country: Leftist Thought in TwentiethCentury America. Harvard University Press, 1998.

32. MITCHAM, C. Thinking Re-Vernacular Building. Des. Issues. 2005, vol. 21, pp. 32-40.

33. FERNG, J. Elemental vernacular: designing beyond human authorship. Architectural theory review: journal of the Department of Architecture, the University of Sydney [online]. December 2015, vol. 20, n. 3, pp. 291-295.

34. SENNETT, R. El artesano. $1^{\text {a }}$ ed. Barcelona: Anagrama, 2009. Colección Argumentos 392.

35. ALEXANDER, C. El modo intemporal de construir. Barcelona: Gustavo Gili, 1981.
30. FARMER, G. From Differentiation to Concretisation: Integrative Experiments in Sustainable Architecture. Societies [online]. 2017. vol. 7, n. 4, p. 35. Available at: https://search.proquest.com/docview/198850461 1 ? accountid $=14712$

31. RORTY, R. Achieving Our Country: Leftist Thought in TwentiethCentury America. Harvard University Press, 1998.

32. MITCHAM, C. Thinking Re-Vernacular Building. Des. Issues. 2005. Vol. 21, pp. 32-40.

33. FERNG, J. Elemental vernacular: designing beyond human authorship. Architectural theory review: journal of the Department of Architecture, the University of Sydney [online]. December 2015. Vol. 20, n. 3, pp. 291-295.

34. SENNETT, R. El artesano. $1^{\text {a }}$ ed. Barcelona: Anagrama, 2009. Colección Argumentos 392.

35. ALEXANDER, C. El modo intemporal de construir. Barcelona: Gustavo Gili, 1981.

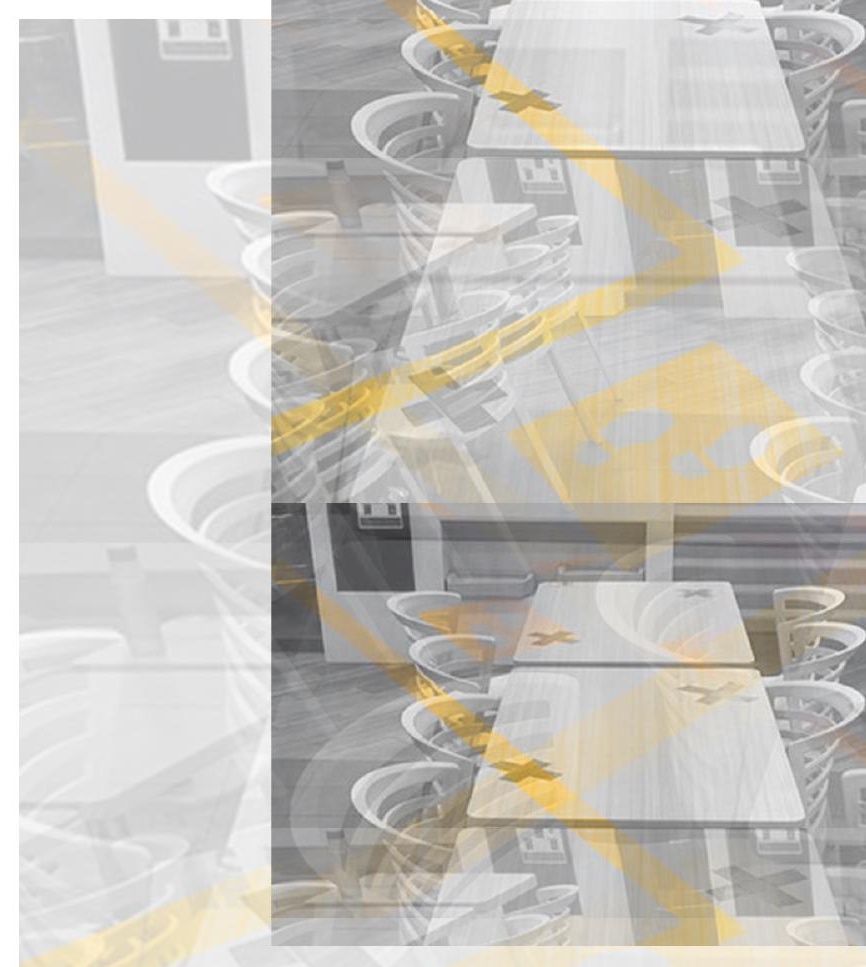

